\title{
PREDIKSI PRESTASI BELAJAR KEWIRAUSAHAAN SISWA SMKN 3 DEPOK BERDASARKAN GAYA BELAJAR MENGGUNAKAN ATURAN MAMDANI
}

\author{
${ }^{1}$ Wulan Anggraeni dan ${ }^{1}$ Indra Suyahya \\ ${ }^{1}$ Dosen Program Studi Pendidikan Matematika Universitas Indrprasta PGRI \\ ${ }^{2}$ Dosen Program Studi Pendidikan Ekonomi Universitas Indrprasta PGRI \\ Email : \\ Wulangussetiyo@gmail.com \\ Indra_suyahya@gmail.com
}

\begin{abstract}
Abstrak
Tujuan dari penelitian ini adalah untuk memperoleh prediksi prestasi belajar ekonomi berdasarkan gaya belajar menggunakan aturan mamdani. Urgensi dari penelitian ini adalah sampai saat ini belum ada penelitian yang memprediksi prestasi belajar ekonomi berdasarkan gaya belajar selain itu hasil prediksi dapat digunakan untuk mengetahui nilai dari prestasi belajar ekonomi berdasarkan gaya belajar. Subyek penelitian dari penelitian ini adalah siswa kelas XI di SMK N 3 Depok. Berdasarkan hasil perhitungan diperoleh bahwa kesalahan prediksi nilai kewirausahaan jurusan pemasaran, perbankan syariah, akuntansi perbankan, dan teknik komputer jaringan secara berturut-turut adalah 18,57 \%; 28,78 \%; 37,2 \%; dan 43,95 $\%$. Hasil prediksi yang memiliki tingkat kesalahan terkecil adalah prediksi prestasi belajar kewirausahaan pada siswa kelas XI jurusan pemasaran, sedangan hasil prediksi yang memiliki tingkat kesalahan tertinggi adalah prediksi prestasi belajar kewirausahaan. Semua hasil prediksi yang diperoleh tidak memuaskan, karena tingkat kesalahannya besar.
\end{abstract}

Kata kunci : Prestasi belajar, kewirausahaan, aturan madani.

\section{PENDAHULUAN}

Hasil penelitian Munawaroh (2015: 586), dalam jurnalnya mengatakan bahwa gaya belajar mahasiswa memiliki pengaruh terhadap prestasi belajar kewirausahaan. Dalam penelitiannya diperoleh hasil bahwa kenaikan 1 satuan gaya belajar akan meningkatkan sebesar 0,32 nilai kewirausahaan, artinya terjadi hubungan positif antara gaya belajar dengan prestasi belajar kewirausahaan.

Beranjak dari hal di atas, timbul suatu pertanyaan, apakah seorang siswa yang memiliki prestasi belajar kewirausahaan tinggi memiliki gaya belajar jenis apa?. Mungkinkah siswa tersebut hanya menonjol di suatu gaya belajar tertentu, misal hanya audio saja yang dimiliki, atau visual saja. Atau 20\% gaya belajar audio, $50 \%$ gaya belajar visual, dan 30\% gaya belajar kinestetik. Untuk itu kita perlu mencari tahu kombinasi gaya belajar yang mana yang menghasilkan prestasi belajar kewirausahaan rendah, sedang atau tinggi. Hal ini dapat dilakukan dengan menerapkan aturan mamdani.

Metode Mamdani sering juga dikenal dengan nama metode Max_Min. Metode ini diperkenalkan oleh Ebrahim Mandani pada tahun 1975. Cara kerja aturan mamdani adalah membentuk himpunan fuzzy, aplikasi fungsi implikas, komposisi aturan dan 
penegasan. Pada metode mamdani, variabel input atau output dibagi menjadi satu atau lebih himpunan fuzzy, fungsi implikasi yang digunakan adalah Min. Komposisi aturan tidak seperti penalaran monoton. Apabila sistem terdiri dari beberapa aturan, maka inferensi diperoleh dari kumpulan dan koralsi antar aturan. Proses defuzzifikasi diperoleh dari komposisi aturan-aturan fuzzy yang diperoleh pada langkah sebelumnya.

\section{TINJAUAN PUSTAKA}

\section{Gaya Belajar}

Menurut DePorter (2002:110-112) mengatakan bahwa, "gaya belajar merupakan suatu kombinasi dari bagaimana seseorang menyerap, dan kemudian mengatur serta mengolah informasi”. Gaya belajar bukan hanya berupa aspek ketika menghadapi informasi, melihat, mendengar, menulis dan berkata tetapi juga aspek pemrosesan informasi sekunsial, analitik, global atau otak kiri-otak kanan, aspek lain adalah ketika merespon sesuatu atas lingkungan belajar.

Keanekaragaman gaya belajar siswa perlu diketahui pada awal permulanya diterima pada suatu lembaga pendidikan yang akan dijalani. Siswa akan dapat belajar dengan baik dan hasil belajar yang baik apabila dia mengerti gaya belajarnya. Hal tersebut memudahkan siswa dapat menerapkan pembelajaran dengan mudah dan tepat. Para peneliti menemukan adanya berbagai gaya belajar pada siswa yang dapat digolongkan menurut kategori-kategori tertentu.

Sedangkan, Winkel (2005:164) mengemukakan bahwa "Gaya belajar merupakan cara belajar yang khas bagi siswa”. Hal ini mengacu pada cara belajar yang khas yang ada pada diri siswa yang lebih disukai pembelajarannya. Umumnya dianggap bahwa gaya belajar seorang berasal dari variabel kepribadian, termasuk susunan kognitif dan psikologis latar belakang sosio-cultural dan pengalaman pendidikan.

Tiap individu memiliki kekhasan sejak lahir dan diperkaya melalui pengalaman hidup. Yang pasti semua orang belajar melalui alat indra, baik penglihatan, pendengaran dan kinestetik. Setiap orang memiliki kekuatan belajar atau gayabelajar. Semakin kita mengenal baik gaya belajar kita maka akan semakin mudah dan lebih percaya diri dalam menguasai suatu kertampilan dan konsep-konsep dalam hidup.

Senada dengan Winkel, Nasution (2008: 93) mengemukakan bahwa,"Gaya belajar atau "learning style" siswa yaitu cara siswa bereaksi dan menggunakan perangsang-perangsang yang diterimanya dalam proses belajar". Kemampuan seseorang 
untuk memahami dan menyerap pelajaran sudah pasti berbeda tingkatnya.Ada yang cepat, sedang, dan ada pula yang sangat lambat. Oleh karena itu, mereka seringkali harus menempuh cara berbeda untuk bisa memahami sebuah informasi atau pelajaran yang sama.

Dari pengertian-pengertian di atas, disimpulkan bahwa gaya belajar adalah cara belajar yang khas yang cenderung dipilih siswa untuk bereaksi dan menggunakan perangsang-perangsang dalam menyerap dan kemudian mengatur serta mengolah informasi pada proses belajar.

Apapun cara yang dipilih, perbedaan gaya belajar itu menunjukkan cara tercepat dan terbaik bagi setiap individu untuk bisa menyerap sebuah informasi dari luar dirinya. Jika kita bisa memahami bagaimana perbedaan gaya belajar setiap orang itu, mungkin akan lebih mudah bagi kita jika suatu ketika misalnya, kita harus memandu seseorang untuk mendapatkan gaya belajar yang tepat dan memberikan hasil yang maksimal bagi dirinya.

\section{Macam-macam gaya belajar}

Kita tidak bisa memaksakan seorang anak harus belajar dengan suasanan dan cara yang kita inginkan karena masing- masing anak memiliki tipe atau gaya belajar sendirisendiri. Kemampuan anak dalam menangkap materi dan pelajaran tergantung dari gaya belajarnya.Banyak anak menurun prestasi belajarnya disekolah karena dirumah anak dipaksa belajar tidak sesuai dengan gayanya. Anak akan mudah menguasai materi pelajaran dengan menggunakan cara belajar mereka masing-masing.

Berdasarkan prefensi sensori atau kemampuan yang dimiliki otak dalam menyerap, mengelola dan menyampaikan informasi, maka gaya belajar individu dapat dibagi dalam 3 (tiga) kategori. Ketiga kategori tersebut adalah gaya belajar visual, auditorial dan kinestetik yang ditandai dengan ciri-ciri perilaku tertentu.

\section{Gaya Belajar Visual}

Menurut Subini (2011:17) gaya belajar visual adalah gaya belajar dengan cara melihat sehingga mata memegang peranan penting. Orang yang memiliki gaya belajar visual akan memiliki kebutuhan yang tinggi untuk melihat dan menangkap informasi secara visual sebelum mereka memahaminya.

Menurut DePorter dan Hernacki (2002) Gaya Belajar Visual (Visual Learners) yaitu gaya belajar menitik beratkan pada ketajaman penglihatan. Artinya, 
bukti-bukti konkret harus diperlihatkan terlebih dahulu agar mereka paham gaya belajar seperti ini mengandalkan penglihatan atau melihat dulu buktinya untuk kemudian bisa mempercayainya.

Menurut Rose Colin dan Nicholl (2002:130) Gaya visual (belajar dengan cara melihat) yaitu belajar harus menggunakan indra mata melalui mengamati, menggambar, mendemonstrasikan, membaca, menggunakan media dan alat peraga. Seorang siswa lebih suka melihat gambar atau diagram, suka pertunjukan, peragaan atau menyaksikan video.Bagi siswa yang bergaya belajar visual, yang memegang peranan penting adalah mata/penglihatan (visual).Dalam hal ini metode pengajaran yang digunakan guru sebaiknya lebih banyak dititik beratkan pada peragaan/media, ajak siswa ke objek-objek yang berkaitan dengan pelajaran tersebut, atau dengan cara menunjukkan alat peraganya langsung pada siswa atau menggambarkannya di papan tulis.

Dari beberapa pendapat di atas dapat disimpulkan bahwa gaya belajar visual adalah gaya belajar dimana mata mempunyai peranan yang sangat penting untuk memahami materi pembelajaran, gaya belajar seperti ini mengandalkan penglihatan atau melihat dulu buktinya untuk kemudian bisa mempercayainya.

\section{Gaya Belajar Auditori}

Menurut Subini (2011:19) gaya belajar auditori yaitu gaya belajar yang dilakukan seseorang untuk memperoleh informasi dengan memanfaatkan indra telinga. Oleh karena itu, mereka sangat mengandalkan telinga untuk mencapai kesuksesan belajar.

Menurut DePorter (2002) Gaya belajar Auditori (Auditory Learners) yaitu gaya belajar dimana mengandalkan pada pendengaran untuk bisa memahami dan mengingatnya. Karakteristik model belajar seperti ini benar-benar menempatkan pendengaran sebagai alat utama menyerap informasi atau pengetahuan.Artinya, kita harus mendengar, baru kemudian kita bisa mengingat dan memahami informasi itu. Karakter pertama orang yang memiliki gaya belajar ini adalah semua informasi hanya bisa diserap melalui pendengaran, kedua memiliki kesulitan untuk menyerap informasi dalam bentuk tulisan secara langsung, ketiga memiliki kesulitan menulis ataupun membaca. 
Menurut Rose Colin dan Nicholl (2002:130) Gaya auditori (belajar dengan cara mendengar) yaitu Belajar haruslah mendengarkan, menyimak, berbicara, presentasi, mengemukakan pendapat, gagasan, menanggapi dan beragumentasi. Seorang siswa lebih suka mendengarkan kaset audio, ceramah-kuliah, diskusi, debat dan instruksi (perintah) verbal. Alat rekam sangat membantu pembelajaran pelajar tipe auditori.

Dari beberapa pendapat di atas dapat disimpulkan bahwa gaya belajar auditori adalah gaya belajar dimana individu memanfaatkan ketajaman indra telinga untuk bisa memahami dan mengingat atau sering disebut dengan belajar dengan cara mendengar.

\section{Gaya Belajar Kinestetik}

Menurut Subini (2011:21) gaya kinestetik merupakan cara belajar yang dilakukan seseorang untuk memperoleh informasi dengan melakukan pengalaman, gerakan dan sentuhan. Selain itu, belajar secara kinestetik berhubungan dengan praktek atau pengalaman belajar secara langsung.

Menurut DePorter dan Hernacki (2002) gaya belajar Kinestetik (Kinesthetic Learners) yaitu gaya belajar yang mengharuskan individu yang bersangkutan menyentuh sesuatu yang memberikan informasi tertentu agar ia bisa mengingatnya.

Menurut Rose Colin dan Nicholl (2002:130) Gaya Kinestetik (belajar dengan cara bergerak, bekerja dan menyentuh) yaitu belajar melalui aktivitas fisik dan keterlibatan langsung. Seorang siswa lebih suka menangani, bergerak, menyentuh dan merasakan/mengalami sendiri, gerakan tubuh (hands-on,aktivitas fisik).Bagi siswa kinestetik belajar itu haruslah mengalami dan melakukan.

Dari beberapa pendapat diatas dapat disimpulkan bahwa gaya belajar kinestetik adalah gaya belajar yang mengharuskan individu yang bersangkutan menyentuh sesuatu yang memberikan informasi tertentu agar ia bisa mengingatnya. mengakses segala jenis gerak dan emosi diciptakan maupun diingat.

Berdasarkan pendapat di atas maka dapat disimpulkan bahwa dengan melihat cara belajar apa yang paling menonjol dari diri seseorang akan mempengaruhi hasil pembelajarannya. Cobalah untuk mulai merenugkan dan mengingat-ingat kembali apa karakteristik belajar anda yang paling efektif. Setelah itu buatlah rencana atau 
persiapan yang merupakan kiat belajar anda sehingga dapat mendukung agar kemampuan tersebut dapat terus dikembangkan.

\section{Teori Himpunan}

Misalkan $S$ adalah himpunan tak kosong, yang dinamakan himpunan semesta yang terdiri atas elemen yang diperhatikan dalam konteks tertentu. Setiap unsur yang berada di dalam himpunan terebut dinamakan elemen atau anggota. $A$ adalah sebuah himpunan sembarang yang merupakan bagian dari himpunan $S$, maka himpunan $A$ merupakan himpunan bagian dari $S$. Untuk menotasikan $s$ merupakan anggota dari himpunan semesta $S$, kita dapat menulisnya menjadi $s \in S$, jika $s$ bukan anggota dari $S$, maka kita dapat menuliskannya menjadi $s \notin \mathrm{S}$, dan untuk menotasikan bahwa $s$ merupakan himpunan bagian dari $S$ adalah $s \subset S$. Jika $s \subset S \vee s=S$, maka notasinya adalah $s \subseteq S$ (Chen: 2001, 1).

Himpunan kosong adalah himpunan yang tidak memilii anggota dinotasikan $\emptyset$. A adalah sebuah himpunan yang anggotanya tertentu dan memiliki sifat $P_{1}, P_{2}, \ldots, P_{n}$ dinotasikan huruf kapital, yaitu: $A=\left\{a \mid a\right.$ memiliki sifat $\left.\mathrm{P}_{1}, \mathrm{P}_{2}, \ldots, \mathrm{P}_{\mathrm{n}}\right\}$.

Jika $R^{n}$ adalah ruang euclid berdimensi $n, A \subseteq R^{n}$ dikatakan konveks jika, $x=$ $\left[\begin{array}{c}x_{1} \\ \vdots \\ x_{n}\end{array}\right] \in A, y=\left[\begin{array}{c}y_{1} \\ \vdots \\ y_{n}\end{array}\right] \epsilon A$ memenuhi syarat $(\lambda x+(1-\lambda) y) \in A$, untuk sembarang $\lambda \in$ $[0,1]$.

Jika $A$ dan $B$ adalah dua buah himpunan. Jika setiap anggota $A$ merupakan anggota dari $B$, maka $A \subset B$. Jika $A \subset B$ dan $B \subset A$, maka kedua himpunan tersebut adalah sama, maka dapat dinotasikan $A=B$. Jika $A \subset B$ atau $A=B$, maka dinotasikan $A \subseteq B$. Olehkarena itu, $A \subset B$ ekuivalen dengan $A \subseteq B$ dan $A \neq B$.

Selisih dari dua buah himpunan $A$ dan $B$ didefinisikan oleh $A-B=$ $\{c \mid c \in A, c \notin B\}$. Untuk kasus tertentu jika $A=S$ (himpunan semesta) maka $S-B$ dinamakan komplemen dari himpunan $B$, dan dinotasikan $\bar{B} \cdot \bar{B}=S-B$. Jelas bahwa $\overline{\bar{B}}=B, \bar{S}=\emptyset$ dan $\bar{\emptyset}=S$. (Chen: 2001, 2).

Misalkan $r \in R$ adalah bilangan real dan $A$ adalah subset dari $R$. Maka perkalian antara $r$ dan $A$ didefinisikan $r A=\{r a \mid a \in A\}$. Gabungan dari dua buah himpunan didefinisikan $A \cup B=B \cup A=\{c \mid c \in A \vee c\} \in B$, dan selalu berlaku $A \cup S=S, A \cup$ $\emptyset=A, A \cup \bar{A}=S$. Irisan pada dua buah himpunan $A$ dan $B$ didefinisikan $A \cap B=B \cap$ 
$A=\{c \mid c \in A, c \in B\}$, jelas bahwa: $A \cap S=A, A \cap \emptyset=\emptyset, A \cap \bar{A}=\emptyset$, dua buah himpunan dikatakan disjoin jika $A \cap B=\emptyset$. (Chen: 2001, 2).

Untuk sembarang himpunan $A$, fungsi karakteristik dari $A$ didefinisikan oleh,

$$
X_{A}(\chi)= \begin{cases}1 & x \in A \\ 0 & x \notin A\end{cases}
$$

\section{Fuzzy}

Himpunan fuzzy mengadopsi pendekatan cara berfikir manusia yang telah dikembangkan dari himpunan teori klasik. Pada himpunan teori klasik dikenal dengan nama fungsi karakteristik. Pada logika fuzzy, anggota dari suatu himpunan tidak seperti pada fungsi karakteristik, yang mengatakan bahwa jika anggota dari suatu himpunan memiliki derajat keanggotaan 1 dan jika bukan anggota himpunan memiliki derajat keanggotaan 0. Dalam himpunan fuzzy, suatu unsur dari himpunan dapat masuk ke dalam beberapa himpunan yang berbeda. pada himpunan fuzzy nilai keanggotaan terletak antara rentang 0 sampai dengan 1. (Chen: 2001, 7).

\section{METODE}

\section{Subyek Penelitian}

Subyek pada penelitian ini adalah siswa kelas XI SMK N 3 Depok. Terdapat 4 jurusan pada kelas XI yakni pemasaran, perbankan syariah, akuntasi perbankan dan teknik komputer jaringan. Banyaknya kelas setiap jurusan secara berturut-turut adalah 1 kelas, 1 kelas, 3 kelas dan 2 kelas. Pada saat skala gaya belajar di sebar tidak semua siswa hadir, dikarenakan ada beberapa siswa yang sudah mulai praktek kerja lapangan. Berikut ini adalah jumlah siswa dari masing-masing jurusan.

Tabel 1. Jumlah Siswa kelas XI SMKN 3 Depok berdasarkan jurusan

\begin{tabular}{|c|c|c|c|c|c|}
\hline No & Jurusan & $\begin{array}{c}\text { Banyaknya } \\
\text { Siswa }\end{array}$ & $\begin{array}{c}\text { Banyaknya siswa yang } \\
\text { mengisi gaya belajar }\end{array}$ & $\begin{array}{c}\text { Data } \\
\text { training }\end{array}$ & $\begin{array}{c}\text { Data } \\
\text { testing }\end{array}$ \\
\hline 1 & Pemasaran & 40 & 25 & 18 & 7 \\
\hline 2 & Perbankan Syariah & 48 & 25 & 18 & 7 \\
\hline 3 & Akuntansi Perbankan & 104 & 66 & 45 & 21 \\
\hline 4 & Teknik Komputer Jaringan & 92 & 52 & 36 & 16 \\
\hline
\end{tabular}

\section{Teknik Analisis}

Prediksi prestasi belajar berdasarkan gaya belajar siswa menggunakan aturan mamdani. Metode mamdani sering juga dikenal dengan nama Metode Max-Min. Metode 
ini diperkenalkan oleh Ebrahim Mamdani pada tahun 1975. Untuk mendaatkan output, diperlukan 4 tahapan:

\section{Pembentukan himpunan fuzzy}

Pada metode mamdani, baik variabel input maupun variabel output dibagi menjadi satu atau lebih himpunan fuzzy.

\section{Aplikasi fungsi implikasi}

Pada metode mamdani, fungsi implikasi yang digunakan adalah Min.

\section{Komposisi aturan}

Tidak seperti penalaran monoton, apabila sistem terdiri dari beberapa aturan, maka inferensi diperoleh dari kumpulan dan korelasi antar aturan, ada 3 metode yang digunakan dalam melakukan inferensi sistem fuzzy, yaitu: max, additive dan probabilistik OR (probor).

\section{Metode Max}

Pada metode ini, solusi himpunan fuzzy diperoleh dengan cara mengambil nilai maksimum aturan, kemudian menggunakannya untuk memodifikasi daerah fuzzy, dan mengaplikasikannya ke output dengan menggunakan operator or. Jika semua proposisi telah dievaluasi, maka output akan berisi suat himpunan fuzzy yang merefleksikan kontribusi dari tiap-tiap proposisi. Secara umum dapat dituliskan:

$$
\mu_{s f}\left[x_{i}\right] \leftarrow \max \left(\mu_{s f}\left[x_{i}\right], \mu_{k f}\left[x_{i}\right]\right)
$$

Dengan:

$\mu_{s f}\left[x_{i}\right]$

: Nilai keanggotaan solusi fuzzy sampai aturan ke-i.

$\mu_{k f}\left[x_{i}\right]$

: Nilai keanggotaan konsekuen fuzzy aturan ke-i.

\section{Metode Additive}

Pada metode ini, solusi himpunan fuzzy diperoleh dengan cara melakukan bounded-sum terhadap semua output daerah fuzzy. Secara umum dituliskan:

$$
\mu_{s f}\left[x_{i}\right] \leftarrow \min \left(\mu_{s f}\left[x_{i}\right], \mu_{k f}\left[x_{i}\right]\right)
$$

Dengan:

$\mu_{s f}\left[x_{i}\right] \quad:$ Nilai keanggotaan solusi fuzzy sampai aturan ke-i.

$\mu_{k f}\left[x_{i}\right] \quad:$ Nilai keanggotaan konsekuen fuzzy aturan ke- $i$. 


\section{Metode Probabilistik OR}

Pada metode ini, solusi himpunan fuzzy diperoleh dengan cara melakukan product terhadap semua output daerah fuzzy. Secara umum dituliskan:

$$
\mu_{s f}\left[x_{i}\right] \leftarrow\left(\mu_{s f}\left[x_{i}\right]+\mu_{k f}\left[x_{i}\right]-\left(\mu_{s f}\left[x_{i}\right] * \mu_{k f}\left[x_{i}\right]\right)\right)
$$

Dengan:

$$
\begin{aligned}
& \mu_{s f}\left[x_{i}\right] \quad: \text { Nilai keanggotaan solusi fuzzy sampai aturan ke- } i \text {. } \\
& \mu_{k f}\left[x_{i}\right] \quad \text { : Nilai keanggotaan konsekuen fuzzy aturan ke-i. }
\end{aligned}
$$

\section{Penegasan}

Input dari proses defuzzifikasi adalah suatu himpunan fuzzy yang diperoleh dari komposisi aturan-aturan fuzzy, sedangkan output yang dihasilkan merupakan suatu bilangan pada domain himpunan fuzzy tersebut. Sehingga jika diberikan suatu himpunan fuzzy dalam range tertentu, maka harus dapat diambil satu nilai crisp tertentu sebagai output. Ada beberapa metode defuzzifikasi pada komposisi aturan mamdani, antara lain:

\section{Metode Centroid}

Pada metode ini, solusi crisp diperoleh dengan cara mengambil titik pusat $z^{*}$ daerah fuzzy. Secara umum dirumuskan:

$$
\begin{aligned}
& z^{*}=\frac{\int_{z} z \mu_{z} d z}{\int_{z} \mu_{z} d z} \\
& z^{*}=\frac{\sum_{j=1}^{n} z_{i} \mu\left(z_{j}\right)}{\sum_{j=1}^{n} \mu\left(z_{j}\right)}
\end{aligned}
$$

\section{Metode Bisektor}

Pada metode ini, solusi crisp diperoleh dengan cara mengambil nilai pada domain fuzzy yang memiliki nilai keanggotaan separo dari jumlah total nilai keanggotaan pada daerah fuzzy. Secara umu dituliskan:

$$
z_{p}=\text { sedemikian hingga } \int_{R_{1}}^{p} \mu_{z} d z=\int_{\rho}^{R_{n}} \mu_{z} d z
$$

\section{Metode mean of maximum}

Pada metode ini, solusi crisp diperoleh dengan cara mengambil nilai rata-rata domain yang memiliki nilai keanggotaan maksimum. 


\section{Metode largest of Maximum}

Pada metode ini, solusi crisp diperoleh dengan cara mengambil nilai terbesar dari domain yang memiliki nilai keanggotaan maksimum.

\section{Metode Smallest of Maximum}

Pada metode ini, solusi crisp diperoleh dengan cara mengambil nilai terkecil dari domain yang memiliki nilai keanggotaan maksimum.

\section{Perhitungan Kesalahan Prediksi}

Pengukuran kesalahan peramalan menggunakan nilai MAPE (mean absolute percentage error) Rumus yang digunakan adalah:

$$
M A P E=\frac{\sum_{t=1}^{n} \frac{\left|Y_{t}-\widehat{Y}_{t}\right|}{Y_{t}}}{n}
$$

\section{HASIL DAN PEMBAHASAN}

\section{Prediksi nilai kewirausahaan jurusan pemasaran}

\section{Fungsi Keanggotaan}

Fungsi Keanggotaan gaya belajar visual

$\mu(v)_{\text {rendah }}=\left\{\begin{array}{cc}0 & x \leq 0 \\ 1 & 0 \leq x \leq 3 \\ \frac{5-x}{2} & 3 \leq x \leq 5\end{array}\right.$

$\mu(v)_{\text {sedang }}= \begin{cases}0 & x \leq 3 \text { atau } \mathrm{x} \geq 8 \\ \frac{x-3}{2} & 3 \leq x \leq 5 \\ \frac{7-x}{2} & 5 \leq x \leq 7\end{cases}$

$\mu(v)_{\text {tinggi }}=\left\{\begin{array}{rl}0 & x \leq 5 \\ \frac{7-x}{2} & 5 \leq x \leq 7 \\ 1 & x \geq 7\end{array}\right.$

Fungsi keanggotaan gaya belajar auditory

$$
\mu(A)_{\text {rendah }}= \begin{cases}0 & x \leq 0 \text { atau } \mathrm{x} \geq 10 \\ 1 & 0 \leq x \leq 8 \\ \frac{10-x}{2} & 8 \leq x \leq 10\end{cases}
$$

$$
\begin{aligned}
& \mu(A)_{\text {sedang }}= \begin{cases}0 & x \leq 8 \text { atau } x \geq 10 \\
\frac{10-x}{2} & 8 \leq x \leq 10 \\
\frac{12-x}{2} & 10 \leq x \leq 12\end{cases} \\
& \mu(A)_{\text {tinggi }}= \begin{cases}0 \leq 10 \text { atau } x \geq 20 \\
\frac{12-x}{2} & 10 \leq x \leq 12 \\
1 & 12 \leq x \leq 20\end{cases}
\end{aligned}
$$

Fungsi keanggotaan gaya belajar kinestetik

$$
\begin{aligned}
& \mu(K)_{\text {rendah }}= \begin{cases}0 & x \leq 0 \text { atau } \mathrm{x} \geq 10 \\
1 & 0 \leq x \leq 8 \\
\frac{10-x}{2} & 8 \leq x \leq 10\end{cases} \\
& \mu(K)_{\text {sedang }}= \begin{cases}\frac{10-x}{2} & 8 \leq x \leq 10 \\
\frac{12-x}{2} & 10 \leq x \leq 12\end{cases} \\
& \mu(K)_{\text {tinggi }}= \begin{cases}0 \frac{0 \text { tau } x \geq 10}{x} \leq 10 \text { atau } x \geq 20 \\
\frac{12-x}{2} & 10 \leq x \leq 12 \\
1 & 12 \leq x \leq 20\end{cases} \\
& \text { Fungsi keanggotaan } \\
& \text { kewirausahaan }
\end{aligned}
$$




$$
\begin{aligned}
& \mu(N K)_{\text {rendah }} \text { atau } x \geq 74 \\
& = \begin{cases}0 \quad x \leq 0 \text { ata } & 0 \leq x \leq 60 \\
\frac{74-x}{14} & 60 \leq x \leq 74\end{cases} \\
& \mu(N K)_{\text {sedang }}= \begin{cases}\frac{0 x \leq 60 \text { atau } x \geq 89}{14-x} & 60 \leq x \leq 74 \\
\frac{89-x}{15} & 74 \leq x \leq 89\end{cases}
\end{aligned}
$$

$$
\begin{aligned}
& \mu(N K)_{\text {tinggi }} \\
& =\left\{\begin{array}{cc}
\frac{90-x}{15} \quad 74 \leq x \leq 89 \\
1 \quad 89 \leq x \leq 100 \\
0 \quad x \geq 100
\end{array}\right.
\end{aligned}
$$

\section{Aturan}

Aturan fuzzy yang dipergunakan dalam penelitian ini berdasarkan data testing yang ada. Adapun aturan yang dipergunakan adalah sebagai berikut:

a. If visual rendah and audio tinggi and kinestetik sedang then nilai kewirausahaan sedang

b. If visual rendah and audio sedang and kinestetik tinggi then nilai kewirausahaan is sedang

c. If visual sedang and audio rendah and kinestetik sedang then nilai kewirausahaan sedang

d. If visual sedang and audio sedang and kinestetik rendah then nilai kewirausahaan rendah

e. If visual sedang and audio sedang and kinestetik sedang then nilai kewirausahaan sedang

f. If visual sedang and audio tinggi and kinestetik rendah then nilai kewirausahaan sedang

g. If visual tinggi and audio rendah and kinestetik sedang sedang then kewirausahaan sedang

\section{Hasil Prediksi}

Tabel 1. Hasil prediksi nilai kewirausahaan siswa kelas XI pemasaran

\begin{tabular}{|c|c|c|}
\hline Siswa & $\begin{array}{c}\text { Nilai } \\
\text { Sebenarnya }\end{array}$ & $\begin{array}{c}\text { Nilai } \\
\text { prediksi }\end{array}$ \\
\hline $\mathbf{1}$ & 45 & 42 \\
\hline $\mathbf{2}$ & 89 & 50 \\
\hline $\mathbf{3}$ & 87 & 74 \\
\hline $\mathbf{4}$ & 81 & 74 \\
\hline $\mathbf{5}$ & 83 & 74 \\
\hline $\mathbf{6}$ & 76 & 50 \\
\hline $\mathbf{7}$ & 83 & 74 \\
\hline
\end{tabular}




\section{Perhitungan kesalahan}

Tabel 2. Perhitungan kesalahan dalam memprediksi nilai kewirausahaan siswa kelas XI jurusan pemasaran

\begin{tabular}{|c|c|c|c|}
\hline Siswa & $\begin{array}{c}\text { Nilai } \\
\text { Sebenarnya }\end{array}$ & Nilai prediksi & $\frac{\left|Y_{t}-\widehat{Y}_{t}\right|}{Y_{t}}$ \\
\hline $\mathbf{1}$ & 45 & 42 & 0.066667 \\
\hline $\mathbf{2}$ & 89 & 50 & 0.438202 \\
\hline $\mathbf{3}$ & 87 & 74 & 0.149425 \\
\hline $\mathbf{4}$ & 81 & 74 & 0.08642 \\
\hline $\mathbf{5}$ & 83 & 74 & 0.108434 \\
\hline $\mathbf{6}$ & 76 & 50 & 0.342105 \\
\hline $\mathbf{7}$ & 83 & 74 & 0.108434 \\
\hline \multicolumn{3}{|c|}{$\sum_{t=1}^{n} \frac{\left|Y_{t}-\widehat{Y}_{t}\right|}{Y_{t}}$} & 1.299687 \\
\hline \multicolumn{3}{|c|}{ MAPE } & 18.56695 \\
\hline
\end{tabular}

\section{Prediksi nilai kewirausahaan jurusan perbankan syariah}

\section{Fungsi Keanggotaan}

Fungsi keanggotaan gaya belajar visual pada siswa kelas XI jurusan perbankan syariah

$$
\begin{aligned}
& \mu(V)_{\text {rendah }}=\left\{\begin{array}{l}
0 \quad x \leq 0 \text { atau } x \geq 6 \\
1 \quad 0 \leq x \leq 4 \\
\frac{6-x}{2} \quad 4 \leq x<6
\end{array}\right. \\
& \mu(V)_{\text {sedang }}=\left\{\begin{array}{cc}
0 \quad x \leq 0 \text { atau } x \geq 9 \\
\frac{6-x}{2} & 4 \leq x<6 \\
\frac{9-x}{2} & 6 \leq x \leq 9
\end{array}\right. \\
& \mu(V)_{\text {tinggi }}=\left\{\begin{array}{cc}
0 \text { atau } x \geq 20 \\
\frac{9-x}{2} & 6 \leq x \leq 9 \\
1 & 9 \leq x \leq 20
\end{array}\right.
\end{aligned}
$$

Fungsi keanggotaan gaya belajar audio pada siswa kelas XI jurusan perbankan syariah

$$
\begin{aligned}
& \mu(A)_{\text {rendah }} \\
& =\left\{\begin{array}{c}
0 \quad x \leq 0 \text { atau } x \geq 10 \\
1 \quad 0 \leq x \leq 7 \\
(10-x) / 3 \quad 7 \leq x \leq 10
\end{array}\right. \\
& \mu(A)_{\text {sedang }}= \begin{cases}0, x \leq 7 \text { atau } x \geq 13 \\
\frac{10-x}{3} & 7 \leq x \leq 10 \\
\frac{13-x}{3} & 10 \leq x<13\end{cases} \\
& \mu(A)_{\text {tinggi }}=\left\{\begin{array}{rl}
0 \quad x \leq 10 \text { atau } x \geq 20 \\
\frac{13-x}{3} & 10 \leq x \leq 13 \\
1 & x \geq 13
\end{array}\right.
\end{aligned}
$$

Fungsi keanggotaan gaya belajar kinestetik pada siswa kelas XI jurusan perbankan syariah

$$
\begin{aligned}
& \mu(K)_{\text {rendah }}=\left\{\begin{array}{l}
0 \quad x \leq 0 \text { atau } x \geq 4 \\
1 \quad 0 \leq x \leq 2 \\
\frac{4-x}{2} \quad 2 \leq x \leq 4
\end{array}\right. \\
& \mu(K)_{\text {sedang }}= \begin{cases}0 \quad x \leq 3 \text { atau } x \geq 7 \\
\frac{4-x}{2} & 2 \leq x \leq 4 \\
\frac{7-x}{3} & 3 \leq x \leq 7\end{cases} \\
& \mu(K)_{\text {tinggi }}=\left\{\begin{array}{cc}
0 \text { atau } x \geq 20 \\
\frac{7-x}{3} & 4 \leq x \leq 7 \\
1 & x \geq 20
\end{array}\right.
\end{aligned}
$$

Fungsi keanggotaan nilai kewiarusahaan pada siswa kelas XI jurusan perbankan syariah

$$
\begin{aligned}
& \mu(K W)_{\text {rendah }}=\left\{\begin{array}{l}
0 \quad x \leq 0 \text { atau } x \geq 77 \\
1 \quad 0 \leq x \leq 55 \\
\frac{77-x}{22} \quad 55 \leq x \leq 77
\end{array}\right. \\
& \mu(K W)_{\text {sedang }}=\left\{\begin{array}{cc}
\frac{77-x}{22} & 55 \leq x \leq 77 \\
\frac{92-x}{25} & 77 \leq x \leq 92
\end{array}\right. \\
& \mu(K W)_{\text {tinggi }}=\left\{\begin{array}{cc}
0 \text { atau } x \geq 100 \\
\frac{92-x}{25} & 7 \leq x \leq 92 \\
1 & 92 \leq x \leq 100
\end{array}\right.
\end{aligned}
$$




\section{Aturan}

Berdasarkan data yang ada kita memperoleh aturan sebagai berikut:

a. If Visual rendah and auditory rendah and kinsetetik tinggi then nilai kewirausahaan tinggi.

b. If visual rendah and auditory sedang and kinestetik sedang then nilai kewirausahaan sedang.

c. If visual sedang and auditori rendah and kinestetik tinggi then nilai kewirausahaa sedang.

d. If Visual sedang and auditory sedang and kinestetik rendah then nilai kewirausahaan sedang.

e. If Visual Sedang and auditory sedang and kinestetik sedang then nilai kewirausahaan tinggi.

f. If visual sedang and auditory tinggi and kenistetik rendah then nilai kewirausahaan tinggi.

g. If Visual tinggi and auditory rendah and kinestetik sedang then nilai kewirausahaan rendah.

h. If visual tinggi and auditory rendah and kinestetik rendah then nilai kewirausahaan tinggi.

\section{Hasil Prediksi}

Tabel 3. Hasil prediksi nilai kewirausahaan siswa kelas XI Perbankan syariah

\begin{tabular}{|c|c|c|}
\hline Siswa & $\begin{array}{c}\text { Nilai } \\
\text { Sebenarnya }\end{array}$ & $\begin{array}{c}\text { Nilai } \\
\text { prediksi }\end{array}$ \\
\hline $\mathbf{1}$ & 78 & 47.8 \\
\hline $\mathbf{2}$ & 56 & 78.2 \\
\hline $\mathbf{3}$ & 76 & 48.3 \\
\hline $\mathbf{4}$ & 87 & 91 \\
\hline $\mathbf{5}$ & 82 & 80.4 \\
\hline $\mathbf{6}$ & 93 & 34.7 \\
\hline $\mathbf{7}$ & 90 & 74.3 \\
\hline
\end{tabular}

\section{Perhitungan kesalahan}

Tabel 4. Perhitungan kesalahan dalam memprediksi nilai kewirausahaan siwa kelas XI jurusan perbankan syariah

\begin{tabular}{|c|c|c|c|}
\hline Siswa & $\begin{array}{c}\text { Nilai } \\
\text { Sebenarnya }\end{array}$ & Nilai prediksi & $\frac{\left|Y_{t}-\widehat{Y}_{t}\right|}{Y_{t}}$ \\
\hline $\mathbf{1}$ & 78 & 47.8 & 0.387179 \\
\hline $\mathbf{2}$ & 56 & 78.2 & 0.396429 \\
\hline $\mathbf{3}$ & 76 & 48.3 & 0.364474 \\
\hline $\mathbf{4}$ & 87 & 91 & 0.045977 \\
\hline $\mathbf{5}$ & 82 & 80.4 & 0.019512 \\
\hline $\mathbf{6}$ & 93 & 34.7 & 0.626882 \\
\hline $\mathbf{7}$ & 90 & 74.3 & 0.174444 \\
\hline \multicolumn{3}{|c|}{$\sum_{t=1}^{n} \frac{\mid Y_{t}-\widehat{Y}_{t}}{Y_{t}}$} & \\
\hline & MAPE & 0.287842 \\
\hline
\end{tabular}




\section{Prediksi nilai kewirausahaan jurusan akuntansi perbankan}

\section{Fungsi Keanggotaan}

Fungsi Keanggotaan gaya belajar visual

$\mu(V)_{\text {rendah }}=\left\{\begin{array}{l}0 \quad x \leq 0 \text { atau } x \geq 6 \\ 1 \quad 0 \leq x \leq 4 \\ \frac{6-x}{2} \quad 4 \leq x \leq 6\end{array}\right.$

$\mu(V)_{\text {sedang }}= \begin{cases}0 & x \leq 4 \text { atau } x \geq 9 \\ \frac{6-x}{2} & 4 \leq x \leq 6 \\ \frac{9-x}{3} & 6 \leq x \leq 9\end{cases}$

$\mu(V)_{\text {ting }}$

$=\left\{\begin{array}{c}0 \quad x \leq 0 \text { atau } x \geq 20 \\ \frac{9-x}{3} \quad 6 \leq x \leq 9 \\ 1 \quad 9 \leq x \leq 20\end{array}\right.$

Fungsi Keanggotaan gaya belajar auditory

$\mu(A)_{\text {rendah }}=\left\{\begin{array}{l}0 \quad x \leq 0 \text { atau } x \geq 9 \\ 10 \leq x \leq 7 \\ \frac{9-x}{2} \quad 7 \leq x \leq 9\end{array}\right.$
$\mu(A)_{\text {sedang }}=\left\{\begin{array}{cc}0 \quad x \leq 0 \text { atau } x \geq 9 \\ \frac{9-x}{2} & 7 \leq x \leq 9 \\ \frac{11-x}{2} & 9 \leq x \leq 11\end{array}\right.$

$\mu(A)_{\text {tinggi }}$

$=\left\{\begin{array}{cc}0 \quad x \leq 9 \text { atau } x \geq 20 \\ \frac{11-x}{2} \quad 9 \leq x \leq 11 \\ 1 \quad 11 \leq x \leq 20\end{array}\right.$

Fungsi Keanggotaan gaya belajar Kinestetik

$$
\begin{aligned}
& \mu(K)_{\text {rendah }}=\left\{\begin{array}{l}
0 \quad x \leq 0 \text { atau } x \geq 4 \\
1 \quad 0 \leq x \leq 2 \\
\frac{4-x}{2} \quad 2 \leq x \leq 4
\end{array}\right. \\
& \mu(K)_{\text {sedang }}= \begin{cases}0 & x \leq 2 \text { atau } x \geq 6 \\
\frac{4-x}{2} & 2 \leq x \leq 4 \\
\frac{6-x}{2} & 4 \leq x \leq 6\end{cases} \\
& \mu(K)_{\text {tinggi }} \\
& =\left\{\begin{array}{c}
0 \quad x \leq 0 \text { atau } x \geq 20 \\
\frac{6-x}{2} \quad 4 \leq x \leq 6 \\
1 \quad 6 \leq x \leq 20
\end{array}\right.
\end{aligned}
$$

Fungsi Keanggotaan nilai belajar kewirausahaan

$$
\begin{aligned}
& \mu(N K)_{\text {rendah }} \\
& =\left\{\begin{array}{l}
0 \quad x \leq 0 \text { atau } x \geq 81 \\
1 \quad 0 \leq x \leq 68 \\
\frac{81-x}{13} \quad 68 \leq x<81
\end{array}\right. \\
& \mu(N K)_{\text {sedang }} \\
& = \begin{cases}0 \quad x \leq 68 \text { atau } x \geq 95 \\
\frac{81-x}{13} & 68 \leq x \leq 81 \\
\frac{95-x}{14} & 81 \leq x \leq 95\end{cases} \\
& \mu(N K)_{\text {ting } i} \\
& =\left\{\begin{array}{c}
0 x \leq 81 \text { atau } x \geq 100 \\
\frac{95-x}{14} 81 \leq x \leq 95 \\
1 \quad 95 \leq x \leq 100
\end{array}\right.
\end{aligned}
$$

\section{Aturan}

Berikut ini adalah aturan fuzzy yang dipergunakan:

a. If visual rendah and audio tinggi and if kinestetik sedang then nilai kewirausahaan sedang

b. If visual rendah and audio sedang and kinestetik sedang then nilai kewirausahaan tinggi

c. If visual rendah and audio rendah and kinestetik sedang then nilai kewirausahaan tinggi

d. If visual rendah and audio sedang and kinestetik tinggi then nilai kewirausahaan tinggi

e. If visual rendah and audio tinggi and kinestetik tinggi then nilai kewirausahaan tinggi

f. If visual sedang and audio tinggi and kinestetik sedang then nilai kewirausahaan sedang 
g. If visual sedang and audio sedang and kinestetik sedang then nilai kewirausahaan tinggi

h. If visual sedang and audio sedang and kinestetik tinggi then nilai kewirausahaan tinggi

i. If visual tinggi and audio sedang and kinestetik sedang then nilai kewirausahaan tinggi

j. If visual tinggi and audio rendah and kinestetik sedang then nilai kewirausahaan tinggi

$\mathrm{k}$. If visual tinggi and audio sedang and kinestetik rendah then nilai kewirausahaan tinggi

1. If visual tinggi and audio tinggi and kinestetik rendah then nilai kewirausahaan tinggi

m. If visual tinggi and audio rendah and kinestetik rendah then nilai kewirausahaan tinggi

\section{Hasil Prediksi}

Tabel 5. Hasil prediksi nilai kewirausahaan siswa kelas XI Akuntansi Perbankan

\begin{tabular}{|c|c|c|c|c|c|}
\hline Siswa & Nilai Asli & Nilai Prediksi & Siswa & Nilai Asli & Nilai Prediksi \\
\hline 1 & 79 & 47.8 & 12 & 88 & 81.3 \\
\hline 2 & 99 & 91.9 & 13 & 78 & 93.6 \\
\hline 3 & 89 & 92.4 & 14 & 50 & 93.6 \\
\hline 4 & 85 & 50 & 15 & 72 & 92.4 \\
\hline 5 & 89 & 92.4 & 16 & 93 & 50 \\
\hline 6 & 83 & 85.8 & 17 & 68 & 92.4 \\
\hline 7 & 78 & 92.4 & 18 & 85 & 38.6 \\
\hline 8 & 88 & 37.1 & 19 & 64 & 92.4 \\
\hline 9 & 59 & 92.4 & 20 & 77 & 92.4 \\
\hline 10 & 91 & 81.3 & 21 & 40 & 81.4 \\
\hline 11 & 49 & 93.6 & & & \\
\hline
\end{tabular}

\section{Perhitungan kesalahan}

Tabel 6. Perhitungan eror dari prediksi nilai kewirausahaan siswa kelas XI Akuntansi Perbankan syariah

\begin{tabular}{|r|r|r|r|r|r|r|r|}
\hline Siswa & $\begin{array}{r}\text { Nilai } \\
\text { Asli }\end{array}$ & $\begin{array}{r}\text { Nilai } \\
\text { Prediksi }\end{array}$ & eror & Siswa & $\begin{array}{r}\text { Nilai } \\
\text { Asli }\end{array}$ & $\begin{array}{r}\text { NIlai } \\
\text { Prediksi }\end{array}$ & $\begin{array}{r}\text { Pror } \\
\text { end }\end{array}$ \\
\hline 1 & 79 & 47.8 & 0.394937 & 12 & 88 & 81.3 & 0.076136 \\
\hline 2 & 99 & 91.9 & 0.071717 & 13 & 78 & 93.6 & 0.2 \\
\hline 3 & 89 & 92.4 & 0.038202 & 14 & 50 & 93.6 & 0.872 \\
\hline 4 & 85 & 50 & 0.411765 & 15 & 72 & 92.4 & 0.283333 \\
\hline 5 & 89 & 92.4 & 0.038202 & 16 & 93 & 50 & 0.462366 \\
\hline 6 & 83 & 85.8 & 0.033735 & 17 & 68 & 92.4 & 0.358824 \\
\hline 7 & 78 & 92.4 & 0.184615 & 18 & 85 & 38.6 & 0.545882 \\
\hline 8 & 88 & 37.1 & 0.578409 & 19 & 64 & 92.4 & 0.44375 \\
\hline 9 & 59 & 92.4 & 0.566102 & 20 & 77 & 92.4 & 0.2 \\
\hline 10 & 91 & 81.3 & 0.106593 & 21 & 40 & 81.4 & 1.035 \\
\hline
\end{tabular}




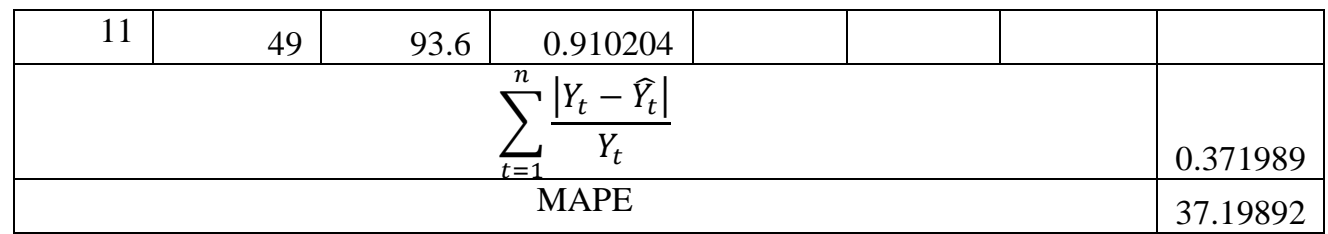

\section{Prediksi nilai kewirausahaan jurusan teknik komputer jaringan}

\section{Fungsi Keanggotaan}

Fungsi keanggotaan gaya belajar visual

$\mu(V)_{r}=\left\{\begin{array}{l}0 \quad x \leq 0 \text { atau } x \geq 6 \\ 1 \quad 0 \leq x \leq 4 \\ \frac{6-x}{2} \quad 4 \leq x \leq 6\end{array}\right.$

$\mu(V)_{s}= \begin{cases}0 & x \leq 4 \text { atau } x \geq 8 \\ \frac{6-x}{2} & 4 \leq x \leq 6 \\ \frac{8-x}{2} & 6 \leq x \leq 8\end{cases}$

$\mu(V)_{t}=\left\{\begin{array}{c}0 x \leq 6 \text { atau } x \geq 20 \\ \frac{8-x}{2} \quad 6 \leq x \leq 8 \\ 1 \quad 8 \leq x \leq 20\end{array}\right.$

Fungsi keanggotaan gaya belajar audio

$$
\begin{aligned}
& \mu(A)_{r}=\left\{\begin{array}{cc}
0 & x \leq 0 \text { atau } x \geq 9 \\
1 & 0 \leq x \leq 7 \\
\frac{9-x}{2} & 7 \leq x \leq 9
\end{array}\right. \\
& \mu(A)_{s} \text { a } x \leq 7 \text { atau } x \geq 12 \\
& =\left\{\begin{array}{cc}
\frac{9-x}{2} & 7 \leq x \leq 9 \\
\frac{12-x}{2} & 9 \leq x \leq 12
\end{array}\right. \\
& \mu(A)_{t}=\left\{\begin{array}{cc}
0 & x \leq 9 \text { atau } x \geq 20 \\
\frac{9-x}{2} & 9 \leq x \leq 12 \\
1 & 12 \leq x \leq 20
\end{array}\right.
\end{aligned}
$$

Fungsi keanggotaan gaya belajar kinestetik

$$
\begin{aligned}
& \mu(K)_{r}=\left\{\begin{array}{cc}
0 & x \leq 0 \text { atau } x \geq 5 \\
\frac{1}{5-x} & 0 \leq x \leq 1
\end{array}\right. \\
& \mu(K) s=\left\{\begin{array}{cc}
\frac{5-x}{4} & 1 \leq x \leq 5 \\
\frac{5-x}{4} & 5 \leq x \leq 5
\end{array}\right. \\
& \mu(K)_{t}=\left\{\begin{array}{cc}
\frac{5-x}{9} & 5 \leq 5 \text { atau } x \geq 20 \\
\frac{9-x}{1} & 9 \leq x \leq 20
\end{array}\right.
\end{aligned}
$$

\section{Fungsi Keanggotaan nilai} kewirausahaan

$$
\begin{aligned}
& \mu(N K)_{R}=\left\{\begin{array}{cc}
0 & x \leq 0 \text { atau } x \geq 77 \\
1 & 0 \leq x \leq 64 \\
\frac{77-x}{13} & 64 \leq x \leq 77
\end{array}\right. \\
& \mu(N K)_{S}=\left\{\begin{array}{cc}
\frac{77-x}{13} & 64 \leq x \leq 77 \\
\frac{91-x}{14} & 77 \leq x \leq 91
\end{array}\right. \\
& \mu(N K)_{T}=\left\{\begin{array}{cc}
\frac{(91-x)}{14} & 77 \leq x \leq 91 \\
\frac{(14}{1} & 91 \leq x \leq 100
\end{array}\right.
\end{aligned}
$$




\section{Aturan}

Berikut ini adalah aturan fuzzy yang dipergunakan dalam prediksi nilai kewirausahaan siswa kelas XI jurusan teknik computer jaringan:

a. If visual rendah and audio sedang and kinestetik sedang then nilai kewirausahaan sedang

b. If visual rendah and audio tinggi and kinestetik sedang then nilai kewirausahaan sedang

c. If visual sedang and audio rendah and kinestetik sedang then nilai kewirausahaan sedang

d. If visual tinggi and audio rendah and kinestetik tinggi then nilai kewirausahaan sedang

e. If visual tinggi and audio rendah and kinestetik sedang then nilai kewirausahaan sedang

f. If visual tinggi and audio sedang and kinestetik sedang then nilai kewirausahaan rendah

g. If visual tinggi and audio sedang and kinestetik tinggi then nilai kewirausahaan tinggi

h. If visual tinggi and audio sedang and kinestetik sedang then nilai kewirausahaan tinggi

\section{Hasil Prediksi}

Berikut ini adalah hasil prediksi nilai kewirausahaan sisswa kelas XI teknik computer jaringan di sajikan pada tabel 5.17

Tabel 7. Hasil prediksi nilai kewirausahaan siswa kelas XI Teknik Komputer Jaringan

\begin{tabular}{|c|c|c|c|c|c|}
\hline Siswa & NIlai Asli & NIlai Prediksi & Siswa & NIlai Asli & NIlai Prediksi \\
\hline 1 & 82 & 50 & 9 & 92 & 50 \\
\hline 2 & 73 & 50 & 10 & 32 & 77.4 \\
\hline 3 & 79 & 77.3 & 11 & 48 & 77.4 \\
\hline 4 & 92 & 77.4 & 12 & 90 & 50 \\
\hline 5 & 55 & 77.3 & 13 & 80 & 50 \\
\hline 6 & 52 & 77.3 & 14 & 87 & 77.4 \\
\hline 7 & 56 & 77.4 & 15 & 85 & 50 \\
\hline 8 & 38 & 77.4 & 16 & 78 & 77.4 \\
\hline
\end{tabular}

\section{Perhitungan kesalahan}

Berikut ini adalah perhitungan kesalahan prediksi.

Tabel 8. Perhitungan eror prediksi nilai kewirausahaan siswa kelas XI Teknik Komputer Jaringan

\begin{tabular}{|r|r|r|r|r|r|r|r|}
\hline Siswa & Nilai Asli & Nllai Prediksi & eror & Siswa & $\begin{array}{r}\text { Nilai } \\
\text { Asli }\end{array}$ & $\begin{array}{r}\text { NIlai } \\
\text { Prediksi }\end{array}$ & $\begin{array}{r}\text { eror } \\
\hline 1\end{array}$ \\
\hline 2 & 50 & 0.390244 & 9 & 92 & 50 & 0.456522 \\
\hline 3 & 73 & 50 & 0.315068 & 10 & 32 & 77.4 & 1.41875 \\
\hline 4 & 79 & 77.3 & 0.021519 & 11 & 48 & 77.4 & 0.6125 \\
\hline 5 & 92 & 77.4 & 0.158696 & 12 & 90 & 50 & 0.444444 \\
\hline 6 & 55 & 77.3 & 0.405455 & 13 & 80 & 50 & 0.375 \\
\hline 7 & 52 & 77.3 & 0.486538 & 14 & 87 & 77.4 & 0.110345 \\
\hline 8 & 56 & 77.4 & 0.382143 & 15 & 85 & 50 & 0.411765 \\
\hline & 38 & 77.4 & 1.036842 & 16 & 78 & 77.4 & 0.007692 \\
\hline
\end{tabular}




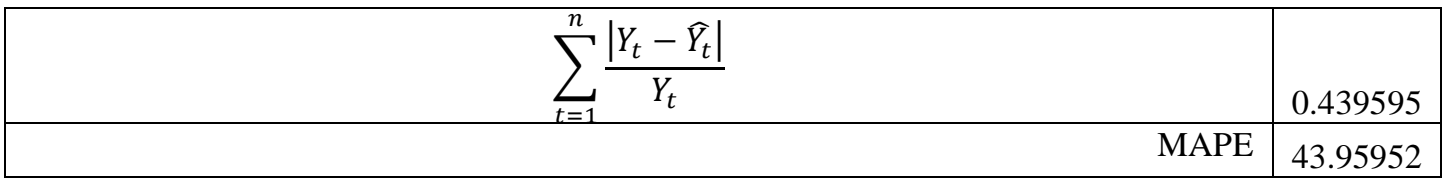

Berdasarkan hasil perhitungan diperoleh bahwa kesalahan prediksi nilai kewirausahaan jurusan pemasaran, perbankan syariah, akuntansi perbankan, dan teknik komputer jaringan secara berturut-turut adalah 18,57 \%; 28,78 \%; 37,2 \%; dan 43,95 \%. Hasil prediksi yang memiliki tingkat kesalahan terkecil adalah prediksi prestasi belajar kewirausahaan pada siswa kelas XI jurusan pemasaran, sedangan hasil prediksi yang memiliki tingkat kesalahan tertinggi adalah prediksi prestasi belajar kewirausahaan. Semua hasil prediksi yang diperoleh tidak memuaskan, karena tingkat kesalahannya besar.

Hasil prediksi yang tidak memuaskan bisa diakibatkan oleh banyak hal, salah satu diantaranya adalah range yang digunakan dalam mengkategorikan gaya belajar visual, gaya belajar audio, gaya belajar kinestetik, dan prestasi belajar kewirausahaan ke dalam range rendah, sedang dan tinggi. Range yang ditetapkan tidak dapat menggambarkan kategori tersebut dengan baik. Selain itu juga dapat diakibatan oleh penentuan aturan yang dipergunakan. Aturan yang dipergunakan dalam penelitian ini bergantung pada data testing yang diperoleh. Data testing yang diperoleh kurang menggambarkan kondisi yang ada.

\section{SIMPULAN}

Berdasarkan hasil perhitungan diperoleh bahwa kesalahan prediksi nilai kewirausahaan jurusan pemasaran, perbankan syariah, akuntansi perbankan, dan teknik komputer jaringan secara berturut-turut adalah 18,57 \%; 28,78 \%; 37,2 \%; dan 43,95\%. Hasil prediksi yang memiliki tingkat kesalahan terkecil adalah prediksi prestasi belajar kewirausahaan pada siswa kelas XI jurusan pemasaran, sedangan hasil prediksi yang memiliki tingkat kesalahan tertinggi adalah prediksi prestasi belajar kewirausahaan. Semua hasil prediksi yang diperoleh tidak memuaskan, karena tingkat kesalahannya besar.

Dikarenakan hasil prediksi yang diperoleh tidak memuaskan, maka perlu dilakukan prediksi nilai kewirausahaan menggunakan metode-metode lainnya. 


\section{DAFTAR PUSTAKA}

Arifin, Z. (2012). Evaluasi Pembelajaran. Bandung: Remaja Rosdakarya.

Chen, G. Pham, T.T, 2001. Fuzzy Sets, Fuzzy Logic, and Fuzzy Control System. CRC Press. New York.

Deporter, B., 2002. Quantum Learning Membiasakan belajar Nyaman dan Menyenangkan. Allyn Bacon. Boston.

Dimyati, Mudjiono. 2006. Belajar dan Pembelajaran. Rineka Cipta. Jakarta.

Lucy. 2016. Tes Minat \& Bakat Anak. Penebar Plus. Jakarta.

Maiyetri, R. Ansofino. 2014. Pengaruh Gaya Belajar Visual, Gaya Belajar Auditorial, dan Kemampuan Berpikir Kritis Terhadap Prestasi Belajar Siswa Kelas XII IPS pada Mata Pelajaran Ekonomi di SMA Negeri 8 Padang. Journal of Economic and Economic Education. 2 (2):100-109.

Munawaroh. 2015. Pengaruh Gaya Belajar dan Lingkungan Belajar terhadap Prestasi Belajar Siswa Pada Mata Pelajaran Kewirausahaan. Prosiding Seminar Nasional. 9 Mei, 2015, Semarang, Indonesia. Hal. 586-596.

Moon, J. (2002). The Module \& Programme Develompment handbook a Practical guide to linking levels, learning outcomes \& asessement. London: Kogan.

Nasution, S. 2008. Berbagai pendekatan dalam Proses BelajarMengajar. Bumi Aksara. Bandung.

Rose, C., Nicholl, M. J. 2002. Accelerated Learning for the 21st Century. Nuansa yayasan Cendikia. Jakarta.

Sardiman, A.M. 2005. Interaksi dan Motivasi Belajar Mengajar. Rajawali Press. Jakarta.

Slameto. 2003. Belajar dan Faktor-Faktor yang Mempengaruhinya. PT Rineka Cipta. Yogyakarta.

Sobry, S. 2009. Belajar dan Pembelajaran. Prospect. Bandung.

Subini, N. 2011. Mengatasi Kesulitan Belajar pada Anak. Javalitera. Yogayakarta.

Thursan, H. 2000. Belajar Secara Efektif. Puspa Swara. Jakarta.

Trianto. 2010. Mendesain Model Pembelajaran Inovatif-Progesif. Kencana. Jakarta.

Witte, R.H. (2012). Clasroom asesment for teachers. Newyork: McGraw-Hill.

Winkle. 2005. Psikologi Pengajaran. Media Abadi. Yogyakarta. 